\title{
Farklı pulpa kaplama materyallerinin toplam oksidan ve antioksidan kapasitelerinin insan dental pulpa kök hücreleri üzerinde değerlendirilmesi ${ }^{\star}$
}

\author{
Seçkin Aksu(0000-0002-5196-215X) ${ }^{\alpha}$, Taşkın Gürbüz(0000-0002-8911-6530 ${ }^{\beta}$
}

Selcuk Dent J, 2020; 7: 192-199 (Doi: 10.15311/selcukdentj.498311)

Başvuru Tarihi: 17 Aralık 2018 Yayına Kabul Tarihi: 17 Nisan 2019

\begin{abstract}
Öz
Farklı pulpa kaplama materyallerinin toplam oksidan ve antioksidan kapasitelerinin insan dental pulpa kök hücreleri üzerinde değerlendirilmesi
\end{abstract}

Amaç: Bu çalışmada Proroot ${ }^{@}$ Mineral Trioksit Agregat (Proroot ${ }^{@}$ MTA), Biodentine ${ }^{T M}$, Pulpine Mineral, Endo Repair ve Çinko Oksit Öjenol (ZnOEu) pulpa kaplama materyallerinin toplam oksidan ve antioksidan seviyelerinin insan dental pulpa kök hücreleri (hDPSCs) üzerinde değerlendirilmesi amaçlanmaktadır.

Gereç ve Yöntemler: Çalışmamızda Amerikan Tipi hDPSCs Kültür Koleksiyonu kullanıldı. Üretici firmaların önerileri doğrultusunda steril kabin içerisinde hazırlanan materyaller, hDPSC ile dolaylı temas sağlamak amacıyla taban çapı $6.5 \mathrm{~mm}$ insert membranların (Falcon ${ }^{\text {TM }}$ Cell Culture Insert, Transparent PET Membran, $3.0 \mu \mathrm{m}$ pore size) tabanını $3 \mathrm{~mm}$ kaplayacak şekilde yerleştirildi. Filtre difüzyon testi, ISO standartlarına göre uygulandı. Biyokimyasal analizler 24. ve 72 . saatlerin sonunda gerçekleştirildi. Ölçümler arasında bağımsız grup karşılaştırmaları için Kruskal Wallis Varyans Analizi ve Mann-Whitney $U$ testi kullanıldı.

Bulgular: Illk 24 saatlik sürede Proroot ${ }^{@}$ MTA, kontrol grubuna benzer antioksidatif koruma gösterirken ( $p>0.05)$, diğer grupların koruyuculuğunun bu seviyenin altında kaldığı tespit edildi. Tüm grupların toplam antioksidatif etkinliğinin 24 ve 72 saat arasında arttığı belirlendi $(p<0.05)$. En yüksek koruma 72 saat sonunda Biodentine $^{T M}$ ve Pulpine Mineral gruplarında, en zayıf koruma ise ZnOEu grubunda gözlemlendi $(p<0.05)$.

Sonuç: Tüm pulpa kaplama materyallerinin insan dental pulpa kök hücreleri üzerinde hem oksidatif etki hem de antioksidan savunma mekanizmasını uyarıcı etkiye sahip olduğu belirlenmiştir. Illk 24 saatte en yüksek korunma Proroot ${ }^{@}$ MTA grubunda, 72 saatte ise; Biodentine $^{\mathrm{TM}}$ ve propolis içeren Pulpine Mineral gruplarında bulunmuştur. ZnOEu grubunun antioksidatif etkisinin yetersiz olduğu tespit edilmiştir. Propolis içerikli pulpa kaplama materyalinin kök hücreler üzerindeki olumlu etkisi nedeniyle kalsiyum fosfat içerikli ürünlere iyi bir alternatif olabileceği düşünülmektedir.

\section{ANAHTAR KELIMELER}

Diş pulpa kaplaması, kalsiyum fosfat, serbest radikaller, propolis

Oksidatif stres, fizyolojik süreçlerde aerobik organizmaların oksijen kullanımının doğal bir sonucu olarak yaklaşık \% 2 oranında meydana gelen ve serbest radikal olarak isimlendirilen reaktif oksijen

\section{ABSTRACT}

Evaluation of total oxidant and antioxidant status of various pulp capping materials on human dental pulp stem cells

Background: The aim of this study was to evaluate the total oxidant and antioxidant status of Proroot ${ }^{@}$ Mineral Trioxide Aggregate (Proroot@ MTA), Biodentine ${ }^{\mathrm{TM}}$, Pulpine Mineral, Endo Repair and Zinc Oxide Eugenol (ZnOEu) on human dental pulp stem cells (hDPSCs).

Methods: In our study, American Type Culture Collection hDPSCs were used. The materials prepared in the sterile cabinet in accordance with the recommendations were placed according to ISO standards in a way to cover the bottom of the $6.5 \mathrm{~mm}$ insert membranes (Falcon ${ }^{\mathrm{TM}}$ Cell Culture Insert, Transparent PET Membrane, $3.0 \mu \mathrm{m}$ pore size) in order to provide indirect contact with the hDPSC. At the $24^{\text {th }}$ and $72^{\text {nd }}$ hours, biochemical analyses were conducted. Kruskal Wallis Variance Analysis and Mann-Whitney $U$ test were used for independent group comparisons between measurements.

Results: As a result of 24 hours evaluation, only Proroot ${ }^{@}$ MTA exhibited antioxidative protection similar to control group $(p>$ 0.05 ), while other groups remained below this level. At the end of $72^{\text {nd }}$ hours, the best preservative groups were Biodentine ${ }^{\mathrm{TM}}$ and Pulpine Mineral, additionally the weakest protective group was $\mathrm{ZnOEu}(p<0.05)$.

Conclusion: It was determined that all pulp capping materials have an oxidative effect and an antioxidant defense mechanism on hDPSCs. The highest protection in the acute exposure was found in the $\operatorname{Proroot}^{@}$ MTA group and additionally, Biodentine ${ }^{\mathrm{TM}}$ and Pulpine Mineral groups were found to be the most protective for a long time. The antioxidative effect of $\mathrm{ZnOEu}$ group was found to be insufficient. Propolis containing pulp capping material is thought to be a good alternative to calcium phosphate products due to its positive effect on stem cells.

\section{KEYWORDS}

Dental pulp capping, calcium phosphate, free radicals, propolis

metabolitlerinin mevcut dengeyi bozacak şekilde birikimi ile meydana gelmektedir. ${ }^{1}$ Bu radikallerin oluşumunun engellenmesi veya neden olduğu hasarların sınırlandırıması için biyolojik sistemlerde

\footnotetext{
*Bu çalışma, Sağlık Bakanlığı tarafindan yayımlanan 19 Ağustos 2011 tarihinde 28030 sayılı "Klinik Araştırmalar Hakkındaki Yönetmelik" hükümlerine bağlı kalınarak ve Atatürk Üniversitesi Diş Hekimliği Fakültesi Dekanlığı Etik Kurulu onayı (06.01.2017/04) alınarak Mayıs 2017 tarihinde Atatürk Üniversitesi Tip Fakültesi Tıbbi Farmakoloji Anabilim Dalı laboratuvarlarinda gerçekleştirilmiştir.

${ }^{\alpha}$ Mersin Üniversitesi Diş Hekimliği Fakültesi Çocuk Diş Hekimliği Anabilim Dalı, Mersin

$\beta$ İstanbul Medeniyet Üniversitesi Diş Hekimliği Fakültesi Çocuk Diş Hekimliği Anabilim Dalı, İstanbul
} 
çeşitli antioksidan savunma mekanizmaları geliştirilmektedir. Endojen veya eksojen kaynaklı olabilen antioksidanlar; canlı hücrelerdeki protein, lipid, karbonhidrat ve deoksiribonükleik asit gibi biyomoleküllerin oksidasyonunu önleyerek veya geciktirerek savunma işlevini yerine getirmektedir.² Farklı oksidan ve antioksidanların spesifik olarak plazma konsantrasyonlarını ölçüm tekniklerinin karmaşık, pahalı ve laboratuvar aşamalarının zaman alıcı olması gibi dezavantajları nedeniyle toplam olarak ölçülmeleri daha basit ve etkin bir yöntemdir. ${ }^{3}$

Diş hekimliği alanında kullanılan materyaller, diğer ksenobiyotikler gibi hücrelerle direkt temas sonucunda redoks düzenleme kapasitesinin üzerinde serbest radikal oluşturarak oksidatif stresi indüklemektedir. Literatürde dental materyallerin prooksidan veya antioksidan aktivitesinin test edilmesini amaçlayan çok az sayıda in vitro ve in vivo biyouyumluluk analiz çalışması bulunmaktadır.4,5 Oksidatif stres durumunun, toksisitenin bir mekanizması olarak kabul görmesinden dolayı materyallerin hücreler üzerinde meydana getirdiği oksidan seviyesinin ve devreye giren antioksidan savunmanın değerlendirilmesi büyük önem taşımaktadır. Süt ve daimi dişlerde uygulanan dentin rejenerasyonuna izin veren vital pulpa tedavilerinde dental pulpa hücreleri ile pulpa kaplama malzemeleri arasındaki etkileşimler, kök hücre proliferasyonunu etkilemektedir. ${ }^{6}$ Tersiyer dentinogenezisin indüklenmesiyle sonuçlanan başarılı bir tedavi için pulpa kaplama materyallerinin, pulpa üzerinde makrofaj ve dev hücrelerin rol aldığı yabancı cisim reaksiyonu şeklindeki kronik bir inflamasyon yerine diş ömrünün kalanı için olumlu bir etki oluşturacak şekilde seçilmeleri son derece önem taşımaktadır.

Mineral Trioksit Aggregat (MTA) ve Biodentin gibi kalsiyum fosfat içerikli materyaller, son yıllarda hücre farklılaşmasını uyararak aktif mineralize doku birikimi sağlayan ideal pulpa kaplama materyalleri olarak kabul görmektedir. ${ }^{7} \quad$ Biyolojik özelliklerinin iyileştirilmesi amacıyla, antienflamatuar ve immunomodulatör etkileri olan, propolis vb doğal antioksidanların eklenmesiyle yeni materyaller geliştirilmeye devam etmektedir. ${ }^{8}$

Bu çalışmanın amacı, çeşitli pulpa kaplama materyallerinin insan dental pulpa kök hücreleri (hDPSCs) üzerindeki Toplam Oksidan Seviyesi (TOS) ve Toplam Antioksidan Seviyesi (TAS)' nin 24 ve 72 saatlik zaman aralıklarında değerlendirilmesidir.

\section{GEREÇ VE YÖNTEM}

\section{Hücre kültürünün hazırlanması}

Çalışmada, Amerikan Tipi Kültür Kolleksiyonu' ndan elde edilmiş dondurulmuş hDPSC (Lonza Pharma \& Biotech, United States, PT-5025, Lot No: 000036115) kullanıldı. Krayoflakonda bulunan $10^{6}$ kadar hücre, 13. pasajda çoğaltıldı. Hızlı bir şekilde ılık distile suda çözülerek yeni besi yeriyle birlikte 5 dakika süre ve $800 \mathrm{rpm}$ devirde santrifüj işlemi (Beckman Coulter, Allegra X-30R Centrifuge, Indiana, United States) gerçekleştirildi. Santrifüj işlemi sonrası üstte kalan sıvı atılarak geriye kalan hücreler, uygun besi yeri (Lonza, Poetics ${ }^{\mathrm{TM}}$, DPSCBM ${ }^{\mathrm{TM}}$, PT-3927, Lot No: 0000505052 , United States) ile karıştıılarak $25 \mathrm{~cm}^{2}$ alanındaki hücre kültürü üretme kabına ekildi. Bir hafta sonunda inverted floresans mikroskop (Leica, Germany) ile hücrelerin üretim kabı tabanının \% 90 ve üzerini kapladıkları tespit edildikten sonra kültür kabındaki besi yeri aspire edildi. Kabın dibinde biriken hücreler, besi yerinin tamamen uzaklaştırıması için pH değeri 7.0 olan Hank'in dengeli tuz solusyonu (Sigma - Aldrich Life Science, United States) ile yıkama işlemine maruz bırakıldı. Tripsin - etilendiamin tetraasetik asit (\% 0.05, \% 0.02, Sigma Aldrich Life Science, United States) solüsyonlarıly karıştırılıktan sonra $37{ }^{\circ} \mathrm{C}$ 'de ve \% $5 \mathrm{CO}_{2}, \% 95$ nemli inkübatörde (Esco CelCulture $\mathrm{CO}_{2}$ İncubator, Friedberg, Germany) 10 dakika inkübe edildi. 15 ml' lik eppendorf tüpüne alınan kültüre Fetal Bovine Serum (Biowest, South America) eklenerek tripsin etkisiz hale getirildi ve tekrar 5 dakika ve 800 1000 rpm devirde santrifüj işlemi gerçekleştirildi. Süpernatant bölüm uzaklaştırılıktan sonra pellet içerisindeki hücreler, hDPSC özel besi yeriyle karıştırlarak Poli-D-Lizin kaplı 24 kuyucuklu plakalara (Sigma - Aldrich Life Science, United States) ekildi ve $\% 5 \mathrm{CO}_{2}, \% 95$ nemli etüvde tekrar inkübe edildi. Etüve bırakılan plakalar içerisindeki besi yeri, üç günde bir yenilendi. Üretim kabı tabanının kaplanma oranı $\% 90$ ve üzeri olduğunda pulpa kaplama materyallerinden elde edilen örneklerin hazırlanması aşamasına geçildi.

\section{Örneklerin hazırlanması}

Deney gruplarını sırasıyla; ProRoot@ MTA (Denstply Tulsa Dental, Tulsa, K, USA), Biodentine ${ }^{\mathrm{TM}}$ (Septodont, Saint Maurdes - Fosses, France), Pulpine Mineral (Hoffmann's Dental Manufactory, Wangenheim, Berlin, Germany), Endo Repair (Hoffmann's Dental Manufactory, Wangenheim, Berlin, Germany) ve Çinko Oksit Öjenol (ZnOEu) (Cavex Holland BV, Haarlem, The Netherlands) pulpa kaplama materyalleri oluşturdu. Üretici firmaların önerileri doğrultusunda steril kabin içerisinde hazırlanan materyaller, siman spatülü ve siman fulvarı yardımıyla hDPSC ile dolaylı temas sağlamak ve dentin tabakasını modellemek amacıyla $3 \mu \mathrm{m}$ boyutlarında açıklıkları bulunan ve taban çapı $6.5 \mathrm{~mm}$ olan insert membranların (Falcon ${ }^{\mathrm{TM}}$ Cell Culture Insert, Tranparent PET Membran, 24 Well $3.0 \mu \mathrm{m}$ pore size) tabanını $3 \mathrm{~mm}$ kaplayacak şekilde yerleştirildi. Tabanına herhangi bir materyal yerleştirilmeyen insert membranlar ise kontrol grubu olarak belirlendi. Her grup için 24 adet hazırlanan membranın sterilizasyon amacıyla bir saat ultraviyole ışınına maruz bırakılmasının ardından, $-80{ }^{\circ} \mathrm{C}$ 'de bekletilen hDPSC dolu 24 kuyucuklu plakalarla birleştirilmesi sağlandı. 


\section{Biyokimyasal analizler}

Kullanılan dental materyallerin zamana bağlı olarak hDPSC üzerine etkilerinin değerlendirilmesi amacıyla TOS ve TAS biyokimyasal analizleri, her gruptaki hücre sıvıları üzerinden 24 ve 72 saat sonunda özel kitler ile ölçüldü.

\section{Toplam oksidan seviyesi}

TOS analizi için ortamdaki ferroz iyonu yapısını ferrik iyonuna kümülatif olarak oksitleyen oksidan mekanizmasından yola çıkılarak asidik ortamda ferrik iyonlarının ksenol orange rengi ile kompleks meydana getirmesi temeline dayanan kolorimetrik yöntem kullanıldı. ${ }^{9}$ Sonuç olarak örneklerdeki oksidan miktarıyla bağlantılı olan renk yoğunluğu, spektrofotometrik olarak değerlendirildi. (Rel Assay Diagnostics ${ }^{\circledR}$, Gaziantep, Turkey).

Hücre sıvilarına $500 \mu \mathrm{l}$ Reaktif 1 (Buffer solüsyonu, $50 \mathrm{ml}$ ) ilave edilerek 530 nm'de ilk absorbans değeri okundu. Daha sonra 25 $\mu \mathrm{l}$ Reaktif 2 (Prokromojen solüsyonu, $10 \mathrm{ml}$ ) eklenerek oda sıcaklığında $10 \mathrm{dk}$ bekletildi. Süre sonunda $530 \mathrm{~nm}$ 'de ikinci absorbans değeri okundu. Elde edilen değerler aşağıdaki formül kullanılarak 'mmol $\mathrm{H}_{2} \mathrm{O}_{2}$ Equiv./ L' cinsinden belirtildi. Standart 2 olarak Stabilize Standart Stok Solüsyonu (800 mm $\mathrm{H}_{2} \mathrm{O}_{2}$ Equiv./L) $10 \mathrm{ml}$ ) kullanıldı.

TOS (mmol $\mathrm{H}_{2} \mathrm{O}_{2}$ Equiv./ $\left.\mathrm{L}\right)=[(\Delta$ Örnek absorbans değeri) $/(\Delta$ Standart 2 absorbans değeri) $] \times 20$

\section{Toplam antioksidan seviyesi}

TAS analizi için, 2-2-azinobis (3-ethylbenzothiazoline 6-sülfonat = $\mathrm{ABTS}^{+}$) olarak ifade edilen özel, renkli bir katyonik radikalin ortamdaki antioksidan moleküllerinin toplam konsantrasyonlarılya orantılı olarak dekolorize olmasını temel alan kolorimetrik yöntem (Rel Assay Diagnostics ${ }^{\circledR}$, Gaziantep, Turkey) kullanıldı. ${ }^{3}$

Hücre sıvilarına $500 \mu \mathrm{l}$ Reaktif 1 (Buffer solüsyonu, $50 \mathrm{ml}$ ) eklenerek 600 nm' de ilk absorbans değerleri okundu. Daha sonra kuyucuklara $75 \mu \mathrm{l}$ Reaktif 2 (Renkli $\mathrm{ABTS}^{+}$solüsyonu,10 ml) eklenerek $10 \mathrm{dk}$ oda sıcaklığında bekletildi. Bekleme sonunda 660 nm'de ikinci absorbans değerleri okundu. Elde edilen absorbans değerleri aşağıdaki formülde uygun şekilde hesaplanarak $E$ vitaminin suda çözünebilen bir analoğu olan ve yüksek hidrofiliklipofilik dengeli antioksidanlardan 'Troloks' maddesine ${ }^{8}$ eşdeğer antioksidan kapasite 'mmol Trolox Equiv./L' cinsinden belirtildi. Standart 1 solüsyonu olarak $10 \mathrm{ml}$ distile su, standart 2 solüsyonu olarak ise; $10 \mathrm{ml} 1.0 \mathrm{mmol}$ Trolox Equiv./L eşdeğer solüsyon kullanıldı.

TAS (mmol Trolox Equiv./L) $=[(\Delta$ Standart 1 absorbans değeri $)-$ ( $\Delta$ Örnek absorbans değeri) $]$ / [( $\Delta$ Standart 1 absorbans değeri) $(\Delta$ Standart 2 absorbans değeri)

\section{İstatistiksel analiz}

Veriler SPSS (Stastistical Package for Social Sciences) 21.0 paket programı kullanılarak analiz edildi. Sürekli değişkenler ortalama \pm standart hata olarak verildi. Ölçümler arasındaki bağımsız grup karşılaştırmalarında Kruskal Wallis Varyans Analizi ve takiben Mann-Whitney $U$ testi kullanıldı. İstatistiksel olarak $p<0.05$ değerleri anlamlı kabul edildi.

\section{BULGULAR}

Çalışma gruplarının TOS sonuçlarına göre Mann-Whitney $U$ istatistiksel analizi sonrası elde edilen ortalama ve standart sapma değerleri Şekil 1 ve Tablo 1'de gösterilmektedir. Her iki zaman diliminde gruplar arasında istatistiksel olarak anlamlı farklılık tespit edilmedi $(p>0.05)$. TOS değerlerinin 24 saate kıyasla 72 saat sonunda $\mathrm{ZnOEu} \mathrm{grubunda} \mathrm{arttığı,} \mathrm{diğer}$ gruplarda azaldığı gözlemlense de bu değişim, istatistiksel olarak anlamlı düzeyde bulunmadı $(p>0.05)$ (Tablo 2$)$.

Tablo 1.

Tablo 1. Çalışma gruplarının 24 saat ve 72 saat sonundaki TOS ortalama ve standart sapma değerleri

\begin{tabular}{lcc|}
\hline Gruplar & \multicolumn{1}{c|}{$\begin{array}{c}\text { 24 Saat } \\
\text { Ortalama } \pm \text { S.S }\end{array}$} & $\begin{array}{c}\text { 72 Saat } \\
\text { Ortalama } \pm \text { S.S }\end{array}$ \\
\hline Kontrol & $12.000 \pm 0.000$ & $12.000 \pm 0.000$ \\
\hline ProRoot $^{\circledR}$ MTA & $16.000 \pm 4.000$ & $10.670 \pm 2.314$ \\
\hline $\begin{array}{l}\text { Biodentine } \\
\text { Pulpine }\end{array}$ & $10.670 \pm 6.111$ & $12.000 \pm 0.000$ \\
\hline $\begin{array}{l}\text { Mineral } \\
\text { Endo Repair }\end{array}$ & $14.670 \pm 2.310$ & $10.670 \pm 2.314$ \\
\hline $\begin{array}{l}\text { ZnOEu } \\
\text { *istatistiksel olarak kontrol grubuna göre anlamlı } \\
\text { farklılığı göstermektedir }(p<0.05) .\end{array}$ \\
$\begin{array}{l}\text { SS: Standart Sapma } \\
\end{array}$
\end{tabular}

Tablo 2.

Mann-Whitney $U$ istatistiksel analizi sonrası elde edilen TOS ' $p$ ' değerlerinin zamana bağlı değişimleri

\begin{tabular}{|c|c|}
\hline Gruplar & $\begin{array}{l}24 \text { - } 72 \text { saat karşılaştırılmalı } \\
\text { TOS analizinde 'p' değerleri }\end{array}$ \\
\hline Kontrol & 1.000 \\
\hline ProRoot $^{\circledR}$ MTA & 0.105 \\
\hline Biodentine $^{\mathrm{TM}}$ & 1.000 \\
\hline Pulpine Mineral & 0.099 \\
\hline Endo Repair & 0.121 \\
\hline ZnOEu & 0.456 \\
\hline
\end{tabular}




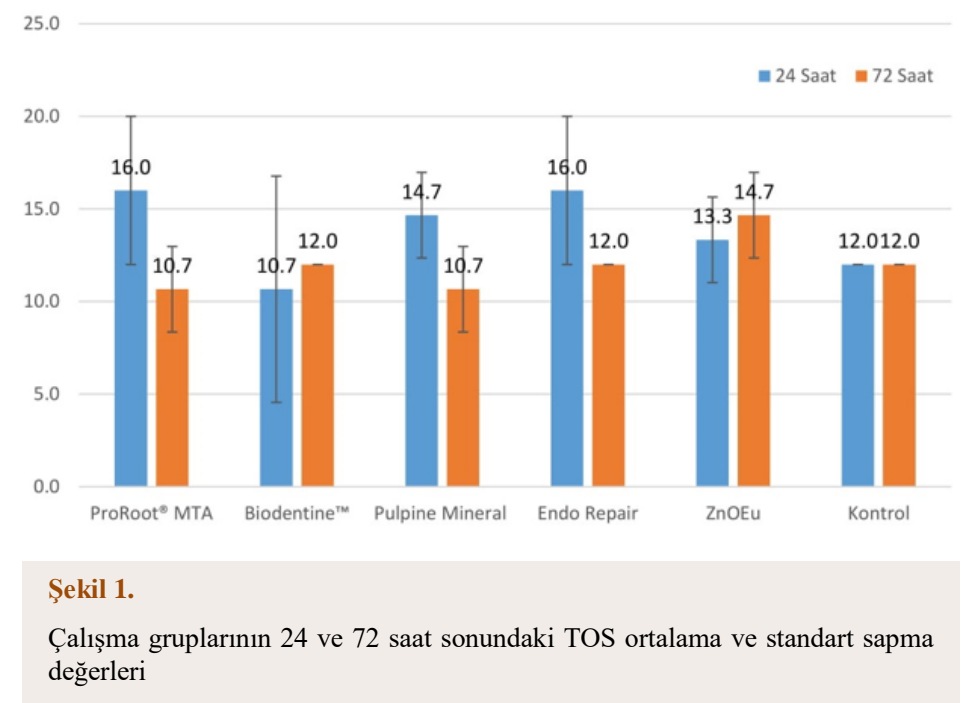

Çalışma gruplarının TAS değerlendirmesi için elde edilen ortalama ve standart sapma değerlerine göre ise; ilk 24 saatte kontrol ve ProRoot ${ }^{\circledR}$ MTA grupları değerleri istatistiksel olarak anlamlı derecede yüksek $(p<0.05)$ bulundu ve iki grup arasında istatistiksel olarak anlamlı farklılık tespit edilmedi ( $p>0.05$ ) (Şekil 2, Tablo 3). Ek olarak, 72 saat sonunda Pulpine Mineral ve $\operatorname{ProRoot}^{\circledR}$ MTA gruplarının TAS değerleri diğer gruplara göre istatistiksel olarak anlamlı şekilde yüksek tespit edildi $(p<0.05)$. Pulpine Mineral- ProRoot $^{\circledR}$ MTA ve Pulpine Mineral- Biodentine ${ }^{\mathrm{TM}}$ grupları arasında istatistiksel olarak anlamlı farklılık tespit edilmedi $(p>0.05)$. Tüm deney gruplarının TAS değerlerinde 72 saat sonunda istatistiksel olarak anlamlı düzeyde artma gözlemlendi $(p<0.05)$ (Tablo 4).

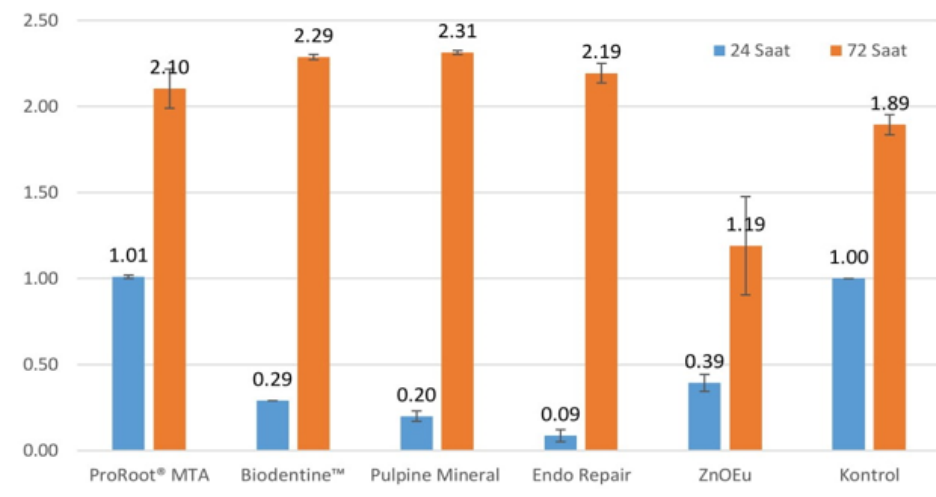

Şekil 2.

Çalışma gruplarının 24 ve 72 saat sonundaki TAS ortalama ve standart sapma değerleri

\section{TARTIŞMA}

Diş hekimliğinde kullanılan birçok materyal yanak, dil, periodonsiyum ve pulpa-dentin kompleksi gibi canlı dokular ile bir araya geldiğinde farklı lokal reaksiyonlar meydana getirebilmektedir. Materyaller üzerinde yapılan biyouyumluluk çalışmaları sayesinde dokular üzerindeki lokal toksik etkilerin değerlendirilmesi mümkün olabilmektedir. ${ }^{10,11}$
Tablo 3.

Çalışma gruplarının 24 saat ve 72 saat sonundaki TAS ortalama ve standart sapma değerleri

\begin{tabular}{|lcc|}
\hline Gruplar & $\begin{array}{c}\text { 24 Saat } \\
\text { Ortalama } \pm \text { S.S }\end{array}$ & $\begin{array}{c}\text { 72 Saat } \\
\text { Ortalama } \pm \text { S.S }\end{array}$ \\
\hline Kontrol & $1.000 \pm 0.000^{*}$ & $1.893 \pm 0.058^{*}$ \\
\hline ProRoot $^{\circledR}$ MTA & $1.010 \pm 0.010$ & $2.103 \pm 0.113^{\star}$ \\
\hline Biodentine $^{\mathrm{TM}}$ & $0.290 \pm 0.000^{*}$ & $2.286 \pm 0.015^{\star}$ \\
\hline Pulpine Mineral & $0.200 \pm 0.030^{*}$ & $2.313 \pm 0.011^{*}$ \\
\hline Endo Repair & $0.086 \pm 0.035^{\star}$ & $2.193 \pm 0.056^{*}$ \\
\hline ZnOEu & $0.393 \pm 0.049^{*}$ & $1.190 \pm 0.285^{\star}$ \\
\hline
\end{tabular}

*istatistiksel olarak kontrol grubuna göre anlamlı farklıı̆ı göstermektedir $(p<0.05)$.

SS: Standart Sapma

\section{Tablo 4.}

Mann-Whitney $U$ istatistiksel analizi sonrası elde edilen TAS ' $p$ ' değerlerinin zamana bağlı değişimleri

\begin{tabular}{|lc|}
\hline Gruplar & $\begin{array}{c}24-72 \text { saat karşılaştırılmalı TAS } \\
\text { analizinde 'p' değerleri }\end{array}$ \\
\hline Kontrol & 1.000 \\
\hline ProRoot $^{\circledR}$ MTA & ${ }^{*} 0.0495(+)$ \\
\hline $\begin{array}{l}\text { Biodentine } \\
\text { TM } \\
\text { Mineral }\end{array}$ & ${ }^{*} 0.037(+)$ \\
\hline $\begin{array}{l}\text { Endo Repair } \\
\text { ZnOEu }\end{array}$ & ${ }^{*} 0.046(+)$ \\
\hline$\quad p<0.05$ & $0.0495(+)$ \\
$+\quad$ TAS değerlerinde istatistiksel olarak 24 saate klyasla 72 \\
saate gözlenen artmayı göstermektedir.
\end{tabular}

Dental materyallerin in vitro koşullarda biyolojik özelliklerini belirlemede en yaygın kullanılan biyolojik sistemler hücre kültürleridir. ${ }^{12}$ Yeni biyomateryallerin özelliklerinin değerlendirilmesi çalışmalarında, dentin rejenerasyonu için büyük önem taşıyan ve farklı hücre populasyonlarına sahip olan pulpa dokusundan elde edilen kök hücrelerden başarıyla yararlanılmaktadır. ${ }^{13}$ Çalışmamızda kullanılmak üzere; elde edilmesinin kolay olması, etik sorun yaratmaması, yüksek proliferasyon ve plastisite yeteneği, biyomateryaller ile dokuların yeniden yapılandırımasında kullanımlarının mümkün olması ve uzun yaşam süreleri gibi nitelikleri dolayısıyla hDPSCs tercih edilmiştir. ${ }^{14-18}$

Test materyali bileşenlerinin difüzyonuna izin veren oluşumlar olan dentin tübüllerini simüle etmek amaciyla bariyer sistemleri geliştirilmiştir. ${ }^{19,20} \mathrm{Bu}$ sistemlerde, materyallerin insert membranlara yerleştirilerek, özel besi yeri bulunan plakalar içerisinde asılı bir şekilde 
şekilde tutulması sağlanmaktadır. Bariyer görevi gören insert membranın alt kısmında bulunan porlar, bileşenlerin geçişine izin vererek besi yeri tabanında bulunan hücrelerle dolaylı temas etmesini sağlamaktadır. ${ }^{21-23}$ Çalışmamızda $3 \mu \mathrm{m}$ boyutlarında por büyüklüğü bulunan insert membran sistemi, ISO 10993 kriterlerine uygun şekilde kullanılmıştır. Üretici firmanın önerilerine uygun olarak hazırlanan materyaller Güven ve ark.'nın çalışmaları ile benzer şekilde insert membranların tabanına $3 \mathrm{~mm}$ yüksekliğinde yerleştirilmiştir. ${ }^{24-26}$

TOS değerlendirmesine göre, 24 ve 72 saat sonunda deney grupları arasında istatistiksel olarak anlamlı bir farklılık tespit edilmemiştir ( $p>0.05)$ (Tablo 1). İlk 24 saate kıyasla 72 saat sonunda hiçbir grupta istatistiksel olarak anlamlı düzeyde artma veya azalma bulunmamıştır $(p<0.05)$. Bu durumda materyallerin hücreler üzerinde meydana getirdiği serbest radikal seviyeleri arasında farklılık bulunmadığı sonucuna varılabilir.

Serbest radikallere karşı savunma kapasitesini belirleyen TAS değerlendirmesinde ilk 24 saatte, sadece ProRoot $^{\circledR}$ MTA uygulanan hücrelerin antioksidatif koruyuculuk sergilediği, diğer grupların bu seviyenin altında kaldıkları tespit edilmiştir $(p<$ 0.05). Tüm materyallerin TAS değerlerinde, 72 saatte istatistiksel olarak anlamlı bir artma saptanmıştır $(p<0.05)$. Uzun dönemde ise, Biodentine $^{\mathrm{TM}}$ ve propolis içerikli Pulpine Mineral materyallerinin en yüksek koruyuculuğa sahip oldukları gözlemlenmiştir $(p<0.05)$.

Biodentin, pulpa kaplama materyali olarak kullanılan bir kalsiyum silikat simanıdır. Odontoblastik tabakanın parsiyel hasarında pulpa iyileşmesinde olumlu etkide bulunduğu belirtilen materyalin birçok hücre tipi üzerinde biyouyumlu olduğunu bildiren pek çok çalışma bulunmaktadır. Ancak hDPSC üzerine sınırlı sayıda araştırma mevcuttur. ${ }^{27-30}$ Zanini ve arkadaşlarının ${ }^{27}$ fare dental pulpa kök hücreleri üzerinde gerçekleştirdikleri çalışmalarında ise, Biodentin maruziyetinden 2 gün sonra hücrelerin canlılığında belirgin bir azalma olduğu ortaya konulmuştur. Yazarlar düşük canlılığın, ortama salınan $\mathrm{Ca}^{+2}$ iyonlarının toksik etki yaratması ve $\mathrm{pH}$ artışının fazla olması nedeniyle oluşabileceğini belirtmişlerdir. Çalışmamızda, Biodentin ${ }^{\mathrm{TM}}$ grubunun TAS değerlerinin 72 saatteki anlamlı artışının nedeni, uzun dönemde ortamda birikmiş olan katyonlara karşı savunmaya yönelik oluşan antioksidan cevabı olabilir.

Aynı zamanda Minamikawa ve ark.nın ${ }^{31}$ odontoblast benzeri hücreler üzerinde yaptıkları çalışmalarında, MTA grubunda özellikle 24 saat sonunda çalışmamızla benzer şekilde yüksek hücre canlıığı ortaya konulmuştur. Farklı sonuçlar, tercih edilen farklı hücre kültürleri veya temas yöntemleri ile ilgili olabilir.
Doğal bir antioksidan olduğu bilinen ${ }^{32,33}$ propolisin yeni pulpa kaplama ajanı olarak içeriğinde yer aldığı Pulpine Mineral materyalinin 24 saat sonunda MTA, Biodentine ${ }^{\mathrm{TM}}$ ve ZnOEu' dan daha az antioksidan özellik geliştirdiği tespit edilmiştir. Fakat 72 saatteki antioksidan savunmanın tüm materyallerden anlamlı düzeyde yüksek olduğu görülmektedir. Pulpine Mineral hakkında daha fazla çalışmaya ihtiyaç duyulmasıyla birlikte hDPSCs üzerinde ilk kez gerçekleştirilen bu çalışma sayesinde, propolis içeren ajanların pulpa kaplaması için de iyi bir alternatif olabileceği sonucuna varılabilir.

MTA, Biodentin, kalsiyumdan zenginleştirilmiş siman ve oktakalsiyum fosfat materyallerinin insan gingival fibroblast hücrelerinin canlıığı üzerindeki etkilerinin değerlendirildiği Farhadmollashahi ve arkadaşlarının ${ }^{25}$ çalışmasında ise, insert membran yöntemi ile 24., 48. ve 168. saatlerde MTT analizi gerçekleştirilmiştir. İlk 24 saatte, tüm materyallerde anlamlı bir farklılık bulunmamakla birlikte geç dönemde, Proroot MTA@ ve Biodentine ${ }^{\mathrm{TM}}$ grupları birbirleriyle benzer ve diğer materyallerden daha az toksik bulunmuştur. Çalışmamızda yer alan kalsiyum fosfat içerikli alternatif bir materyal olarak geliştirilen Endo Repair materyalinin iki zaman aralığında da diğer materyallerle karşılaştırıldığında antioksidan özelliğini tam olarak gösteremediği ve benzer şekilde Proroot MTA@ ${ }^{@}$ ve Biodentine ${ }^{\mathrm{TM}}$ gruplarının daha etkili bir koruyuculuk sergilediği görülmektedir.

ZnOEu' un fenolik komponentinin antioksidan özelliğinin yüksek olduğu, öte yandan pulpa dokusuna direkt uygulandığında yüksek dozda öjenol serbestlenmesiyle birlikte sitotoksik etki gösterdiği bilinmektedir. ${ }^{34,35}$ Çalışmamızda, ilk 24 saatte ZnOEu' nun Proroot MTA@ ve kontrol grubu haricindeki gruplara göre antioksidan aktivitesinin daha fazla olduğu $(p<0.05)$ fakat bu koruyucu etkinliğini 72 saate kadar devam ettiremediği ve 72 saat sonunda TAS değerinin diğer gruplarla karşılaştırıldığında istatistiksel olarak anlamlı şekilde düşük bulunduğu gösterilmiştir $(p<0.05)$.

\section{SONUÇ}

Çalışmamızda kullanılan materyallerin 24 ve 72 saat sonunda hDPSCs üzerinde benzer bir oksidatif etki meydana getirdikleri tespit edilmiştir. İlk 24 saatte sadece ProRoot $^{\circledR} \quad$ MTA grubunun antioksidatif savunma mekanizmasının kontrol grubuyla benzer şekilde yüksek olduğu gösterilmiştir. Tüm grupların antioksidatif savunma düzeyinde 24. ve 72. saatler arasında artış meydana geldiği, en uzun süreli koruyuculuğun Biodentine ${ }^{\mathrm{TM}}$ ile propolis içerikli Pulpine Mineral gruplarında ve en zayıf koruyuculuğun ZnOEu grubunda olduğu tespit edilmiştir. Propolis içerikli pulpa kaplama materyalinin, kök hücrelerin antioksidan savunma kapasitesini arttırmaya yönelik olumlu etkisi nedeniyle kalsiyum fosfat içerikli ürünlere iyi bir alternatif olabileceği gösterilmiştir. Klinik açıdan başarılı materyallerin biyouyumluluklarını arttırmaya yönelik girişimlerin ön planda olduğu daha uzun süreleri kapsayan ileri çalışmalara intiyaç duyulmaktadır. 


\section{Teşekkür}

Çalışma, Atatürk Üniversitesi Bilimsel Araştırma Projeleri Koordinatörlüğü tarafından (PRJ2015/308) kodlu proje ile desteklenmiştir. Şili' de 4-7 Ekim 2017 tarihleri arasında düzenlenen Uluslararası Çocuk Diş Hekimliği Derneği Kongresi (International Association of Paediatric Dentistry Congress)' nde 'Evaluation of Total Antioxidant-Total Oxidant Status of Various Pulp Capping Materials on Human Dental Pulp Stem Cells' konu başlığı ile tebliğ edilmiştir. Çalışmaya katkılarından dolayı Atatürk Üniversitesi Tıp Fakültesi Tıbbi Farmakoloji Anabilim Dalı' na ve Atatürk Üniversitesi Diş Hekimliği Fakültesi Çocuk Diş Hekimliği Anabilim Dalı' nda görev yapmakta olan Dr. Öğr. Üyesi Fatih Şengül'e teşekkürlerimizi sunarız. 


\section{KAYNAKLAR}

1. Schieber $M$, Chandel $N$. ROS function in redox signaling and oxidative stress. Curr Biol 2014; 24.10: 453-62.

2. Noctor G, Mhamdi A, Foyer C. Oxidative stress and antioxidative systems: recipes for successful data collection and interpretation. Plant Cell Environ 2016; 39.5: $1140-60$.

3. Erel O. A novel automated direct measurement method for total antioxidant capacity using a new generation, more stable ABTS radical cation. Clin Biochem 2004; 37.4: 277-85.

4. Taso E, Stefanovic V, Stevanovic I, Vojvodic D, Topic A, Petkovic-Curcin A, et al. Influence of Dental Restorations on Oxidative Stress in Gingival Crevicular Fluid. Oxid Med Cell Longev 2018; 1-17.

5. Oktay E, Tort H, Yıldız O, Ulusoy K, Topcu F, Ozer C. Dental resin curing blue light induces vasoconstriction through release of hydrogen peroxide. J Photochem Photobiol B 2018; 185: 41-5.

6. Gomes-Cornélio A, Rodrigues E, Salles L, Mestieri L, Faria G, Guerreiro-Tanomaru J, et al. Bioactivity of MTA Plus, Biodentine and an experimental calcium silicate-based cement on human osteoblast-like cells. Int Endod J 2017; 50(1): 39-47.

7. Bhat S, Hegde S, Adhikari F, Bhat V. Direct pulp capping in an immature incisor using a new bioactive material. Contemp Clin Dent 2014; 5(3): 393-6.

8. Ahangari Z, Naseri M, Vatandoost F. Propolis: Chemical Composition and Its Applications in Endodontics. Iran Endod J 2018; 13(3): 285-92

9. Regoli F, Winston G. Quantification of total oxidant scavenging capacity of antioxidants for peroxynitrite, peroxyl radicals, and hydroxyl radicals. Toxicol Appl Pharmacol 1999; 156(2): 96-105.

10.Wataha JC. Principles of biocompatibility for dental practitioners. J Prosthet Dent 2001;86(2):203-9.

11. Hanks CT, Wataha JC, Sun Z. In vitro models of biocompatibility: a review. Dent Mater 1996; 12(3): 186-93.

12.Tuncer S, Demirci M. Dental materyallerde biyouyumluluk değerlendirmeleri. Atatürk Üniv Diş Hek Fak Derg 2011; 21: 141-9.

13. Mestieri L, Gomes-Cornelio A, Rodrigues E, Salles LP, Bosso-Martelo R, Guerreiro-Tanomaru J, et. al. Biocompatibility and bioactivity of calcium silicatebased endodontic sealers in human dental pulp cells. J Appl Oral Sci 2015; 23(5): 467-71.

14.Atalayın Ç, Ergücü Z, Tezel H. Diş hekimliğinde kök hücre ve dental pulpa kök hücreleri. Acta Odontologica Turcica 2012; 29: 115-9.

15. Gronthos S, Mankani M, Brahim J, Robey PG, Shi S. Postnatal human dental pulp stem cells (DPSCs) in vitro and in vivo. Proc Natl Acad Sci U S A 2000; 97(25): 13625-30.
16. Verma K, Bains R, Bains V, Rawtiya M, Loomba K, Srivastava S. Therapeutic potential of dental pulp stem cells in regenerative medicine: An overview. Dent Res J (Isfahan) 2014; 11(3): 302-8.

17.Graziano A, d'Aquino R, Laino G, Papaccio G. Dental pulp stem cells: a promising tool for bone regeneration. Stem Cell Rev 2008; 4(1): 21-6.

18.Tekeli S, Arısu Naghavi E, Gökçe B, Sır G, Yiğittürk G, Çavuşoğlu T, et al. Kök hücreler; mezenkimal kök hücreler ve güncel klinik uygulamaları. FNG \& Bilim Tıp Transplantasyon Dergisi 2016; 1(2): 72-83.

19. Murray P, Godoy C, Godoy F. How is the biocompatibilty of dental biomaterials evaluated? Med Oral Patol Oral Cir Bucal 2007; 12(3): E258-66.

20.Sjögren G, Sletten G, Dahl J. Cytotoxicity of dental alloys, metals, and ceramics assessed by millipore filter, agar overlay, and MTT tests. J Prosthet Dent 2000; 84(2): 229-36.

21. Merdad K, Pascon A, Kulkarni G, Santerre P, Friedman $\mathrm{S}$. Short-term cytotoxicity assessment of components of the epiphany resin-percha obturating system by indirect and direct contact millipore filter assays. J Endod 2007; 33(1): 24-7.

22. Saw T, Cao T, Yap A, Lee N. Tooth slice organ culture and established cell line culture models for cytotoxicity assessment of dental materials. Toxicol In Vitro 2005; 19(1): 145-54.

23. Browne R, Tyas M. Biological testing of dental restorative materials in vitro--a review. J Oral Rehabil 1979; 6(4): 365-74.

24. Guven G, Cehreli Z, Ural A, Serdar M, Basak F. Effect of mineral trioxide aggregate cements on transforming growth factor $\beta 1$ and bone morphogenetic protein production by human fibroblasts in vitro. J Endod 2007; 33(4): 447-50.

25. Farhadmollashahi N, Ghotbi F, Karkeabadi H, Havaei R. Cytotoxic effects of mineral trioxide aggregate, calcium enrichedmixture cement, Biodentine and octacalcium pohosphate onhuman gingival fibroblasts. J Dent Res Dent Clin Dent Prospects 2016; 10(2): 75-80.

26. Saberi E, Karkehabadi H, Mollashahi N. Cytotoxicity of Various Endodontic Materials on Stem Cells of Human Apical Papilla. Iran Endod J 2016; 11(1): 1722.

27.Zanini M, Sautier J, Berdal A, Simon S. Biodentine induces immortalized murine pulp cell differentiation into odontoblast-like cells and stimulates biomineralization. J Endod 2012; 38(9): 1220-6.

28. Koubi G, Colon P, Franquin J, Hartmann A, Richard $G$, Faure $M$, et al. Clinical evaluation of the performance and safety of a new dentine substitute, Biodentine, in the restoration of posterior teet--a prospective study. Clin Oral Investig 2013 Jan; 17(1): 243-9. 
29. Agrafioti A, Taraslia V, Chrepa V, Lymperi S, Panopoulos P, Anastasiadou E, et al. Interaction of dental pulp stem cells with Biodentine and MTA after exposure to different environments. J Appl Oral Sci 2016; 24(5): 481-6.

30.E Peng W, Liu W, Zhai W, Jiang L, Li L, Chang J,et al. Effect of tricalcium silicate on the proliferation and odontogenic differentiation of human dental pulp cells. J Endod 2011; 37(9): 1240-6.

31. Minamikawa H, Yamada M, Deyama Y, Suzuki K, Kaga M, Yawaka $\mathrm{Y}$, et al. Effect of $\mathrm{N}$-acetylcysteine on rat dental pulp cells cultured on mineral trioxide aggregate. J Endod 2011; 37(5): 637-41.

32.Pascual C, Gonzalez R., Torricella R. Scavenging action of propolis extract against oxygen radicals. $\mathrm{J}$ Ethnopharmacol 1994; 41(1-2): 9-13.

33. Mujica V, Orrego R, Pérez J, Romero P, Ovalle P, Zúñiga-Hernández $\mathrm{J}$. The role of propolis in oxidative stress and lipid metabolism: a randomized controlled trial. E Evid Based Complement Alternat Med 2017; 1-11.

34. Lee JH, Lee HH, Kim HW, Yu JW, Kim KN, Kim KM. Immunomodulatory/anti-inflammatory effect of ZOE-based dental materials. Dent Mater 2017; 33(1): e1-e12.

35. Malkoç M, Demir N, Şengün A, Bozkurt Ş, Hakki S. Cytotoxicity of temporary cements on bovine dental pulp-derived cells (bDPCs) using realtime cell analysis. J Adv Prosthodont 2015; 7(1): 21-6.

Yazışma Adresi:

Seçkin AKSU

Mersin Üniversitesi, Diş Hekimliği Fakültesi

Çocuk Diş Hekimliği $A D$

Çiftlikköy Kampüsü 33110 Yenişehir, Mersin

Tel : +903243610035

GSM : +905365267271

Faks : +903243610369

E Posta: dtseckinaksu@gmail.com 